\title{
PERGESERAN MAKNA, FUNGSI, DAN BENTUK TEMBIKAR TRADISIONAL SUNGAI JANIAH DI TANAH AGAM SUMATRA BARAT
}

\author{
Nuning Y Damayanti dan Mesra
}

\begin{abstract}
The background of the establishment of the earthenware craft of Sungai Janiah is acquired from the legend The Sacred Fish, which is a "karma" of the nature's authority against a mother who neglected the care of her child, so that the child be came a fish. Since then every mother is forbidden to leave her child alone at home. The mother may work at home while taking care of her children. The work chosen is making earthenware, because the easily available raw material, and easily done. The philosophy of the earthenware of Sungai Janiah is "Mother and Child Philosophy". This is reflected by the attitude and behaviour in making earthenware like child-caring, and each stage of making earthenware is based on that. The traditional earthenware craft today is decreasingly developing due to its inability to compete with industrial products. The problems most commonly faced are the technological development- and the marketing problems. This study was done in Sungai Janiah Kabupaten Agam, West Sumatera, because it has never before research has been done in this field, and no written reference yet exists concerning this craft. This study had to be done so the nation's cultural asset will be not forgotten without more and is needed for the scientific world. The method of study used is the qualitative method with the cultural approach. Data of study was acquired by direct observation, and interviews and field notes were made concerning matters that can support the study findings. The study findings can be explained as follow:Commonly the earthenware of Sungai Janiah is round-formed, functioning as household utensils receptacles. The Sungai Janiah earthenware has not experienced many changes in form, but in function and meaning. No changes in form is due to the limited capacity of the craftsmen and the local socio-cultural factor. The change in meaning is due to scientific developments and socio-cultural changes.
\end{abstract}

Keywords: Legend of Agam society, Tembikar Janiah as a Women Creation and Traditional Technology, Tembikar Janiah River,

\section{PENDAHULUAN}

Sumatera Barat merupakan salah satu daerah di Indonesia yang telah lama dikenal sebagai penghasil kerajinan tembikar. Ada beberapa sentra kerajinan tembikar tradisional di Sumatera Barat, seperti daerah Galogandang Kabupaten Limapuluh Kota, daerah Galo-gandang Kabupaten Tanah Datar, dan daerah Sungai Janiah Kabupaten Agam.

Kerajinan tembikar Sungai Janiah memiliki beberapa ciri yang berbeda dari daerah lain. Ciri-ciri yang berbeda dari setiap daerah itu kemudian dikenal dengan lokal genius (local genius). Perbedaan itu misalnya landasan atau gagasan munculnya kerajinan tembikar, proses pembe- ntukan, atau pun teknologi yang digunakan. Keunikan pembuatan tembikar Sungai Janiah misalnya dibentuk sambil dipangku di atas pelukan pengerajin yang duduk berselunjur. Setiap tahap pembentukan tembikar diberi nama seperti aktivitas mengasuh anak. Pengerajin tidak meng-gunakan alat putar keramik dan tidak pula meng-gunakan papan kecil sebagai alas. Meskipun dem-ikian hasil yang mereka buat sangat simetris, ke-tebalannya juga merata kirakira $4-7 \mathrm{~mm}$, serta permukaannya halus/licin dan tidak merembes air.

Desa Sungai Janiah terletak di Kecamatan Baso Kabupaten Agam Sumatera Barat, kira-kira 15 kilo meter dari kota Bukittinggi. Desa ini cukup lama terisolir yaitu 
tidak ada kendaraan, listrik, lembaga pendidikan, dan lembaga pela-yanan kesehatan. Barangbarang industri modern tidak cepat masuk dan kerajinan tradisional dapat bertahan. Mata pencaharian utama masyara-katnya adalah bertani, di samping menjual kayu api, dan kerajinan tembikar.

Pembuatan tembikar di Sungai Janiah pada aw-alnya adalah untuk keperluan wadah, seperti tempat memasak makanan, tempat makan-minum, tempat menyimpan bahan makanan, sebagai upaya memenuhi kebutuhan sendiri atau keluarga, tetapi kemudian berkembang menjadi kebutuhan komersial. Fungsi tembikar kemudian juga berkembang sebagai perangkat upacara ritual seperti : tempat membakar kemenyan pada upa-cara syukuran, upacara penyemaian benih (padi), perbaikan irigasi, panen bersama, ziarah kubur, dan ziarah ke tempat-tempat yang dianggap kera-mat. Pada waktu menyambut bulan suci rama-dhan juga ada digunakan tembikar yang khusus guna memasak air kembang (biasanya masyarakat mandi kembang yang disebut dengan "Balimau"). Kembang yang digunakan bernama "bungo rampai".

Kerajinan tembikar Sungai Janiah ini pernah mengalami kejayaannya semenjak awal tahun 1950-an hingga akhir tahun 1960-an, yaitu setiap rumah penduduk merupakan tempat pro-duksi tembikar. Kemudian setelah banyaknya produk-produk industri yang masuk meng-gan-tikan peran dari barang-barang tembikar, maka secara berangsur-angsur produksinya berkurang karena rendahnya permintaan kon-sumen. Aneh-nya para pengerajin tidak men-ciptakan bentuk-bentuk lain, untuk meng-antisipasi kalau produk mereka sudah digantikan oleh produk industri. Akibatnya potensi desa sebagai sentra kerajinan tembikar menjadi tidak berkembang, sementara persediaan bahan baku dan tenaga kerja cukup banyak.

Persoalan yang menarik untuk diteliti dari kerajinan tembikar tradisional di Sungai Janiah adalah, bahwa kerajinan ini sudah

244 | Jurnal Budaya Nusantara Vol. 2 No. 1 berlangsung dalam kurun waktu yang sangat lama, tetapi mengapa tidak terjadi perubahanperubahan be-ntuk artefaknya? Hal ini terungkap ketika penulis melakukan studi kelayakan penelitian, dimana pe-ngerajin mengatakan bahwa bentuk-bentuk tem-bikar yang mereka buat sekarang juga sama de-ngan yang sudah ada pada zaman Belanda dulu. Bukankah sudah puluhan kali pergantian generasi penerus yang melanjutkan kerajinan tembikar ter-sebut, seharusnya terjadi transformasi atau peru-bahan bentuk seiring dengan transformasi budaya lainnya. Masyarakat pendukung sangat kuat ter-hadap tradisi atau keyakinan-keyakinan lama, yang menjadikan produk budaya abadi karena tid-ak terjadi perubahan teknologi.Sekarang Kera-jinan tembikar tradisional Sungai Janiah terjadi penurunan dalam jumlah produksi yang disebab-kan rendahnya permintaan konsumen, Hal ini yang perlu diusahakan pemercahan masalah ini revitalisasi atau pun pengembangan yang dapat menarik pangsa pasar.

Kerajinan tembikar memiliki pluralitas atau keragaman yang menjadi ciri lokal (local genius) dan dapat memperkaya budaya nasional. Kerajinan ini sudah menjadi tradisi dalam kurun waktu yang lama, tetapi belum ada sejarah tertulis yang dapat dipelajari dan pendokumentasian ke-unikan bentuk-bentuk produk tembikar tersebut. Hal ini sangat penting untuk diteliti dan dide-skripsikan sehingga suatu saat dapat dibaca oleh orang-orang yang membutuhkannya. Hal yang penting lainnnya untuk masa mendatang agar kerajinan tembikar ini tetap bertahan diproduksi dan dapat dikembangkan lagi menjadi kerajinan seni yang unik memperkaya wujud dan tehnik pembuatan tembikar terakota Indonesia, sebagai produk budaya masyarakat setempat, dan dapat menopang otonomi daerah Kabupaten Agam Sumatera Barat.

\section{DASAR TEORITIS}

Perkembangan teknologi industri dalam pembuatan barang-barang keperluan rumah tan- 
gga dewasa ini meningkat sekali sehingga barang-barang hasil kerajinan tangan semakin tergeser kedudukannya. Selain itu,kemajuan teknologi dan proses modernisasi juga membuat lunturnya nilai-nilai tradisi warisan leluhur masayarkat Sumatra Barat. Terkait dengan hal tersebut, bagaimanakah pergeseran makna, fungsi, dan bentuk tembikar tradisional Sungai Janiahdi Tanah Agam Sumatra Barat?

\section{Lingkungan Geografi dan Kondisi Sosial Ma-syarakat Sungai Janiah di Tanah Agam Su-matra Barat.}

Secara geografis lingkungan alam Desa Sungai Janiah merupakan daerah perbukitan yang merupakan bahagian dari gugusan Bukit Barisan pulau Sumatera, tepatnya desa ini berada di kaki Bukit Kubuang Tigo Baleh. Berdasarkan do-kumentasi dari Kantor Desa Sungai Janiah, tang-ga 10 Maret 2003, dapat diuraikan monografi De-sa Sungai Janiah sebagai berikut.

Desa Sungai Janiah berada pada ketinggian 905 meter di atas permukaan laut, dengan suhu udara antara 21o $\mathrm{C}$ pada malam hari, sampai 30o C pada siang hari. Desa Sungai Janiah ber-batasan dengan desa-desa tetangga sebagai ber-ikut : Sebelah Barat berbatasan dengan desa Koto Baru, sebelah Timur berbatasan dengan desa Ka-mpeh, sebelah Utara berbatasan dengan desa Sa-lo, sebelah Selatan berbatasan dengan desa Tabek Panjang.Kemudian dari luas wilayah Desa Sungai Janiah dapat dibagi berdasarkan fungsi atau pemanfaatan area sebagai berikut

\begin{tabular}{|c|l|c|}
\hline No & Pemanfaatan Lahan & $\begin{array}{c}\text { Luas } \\
\text { dalam } \\
\text { Hektar }\end{array}$ \\
\hline 1 & Sawah & 150 Hektar \\
\hline 2 & Ladang & 62 Hektar \\
\hline 3 & Pemukiman/perumahan & 94 Hektar \\
\hline 4 & Hutan & 15 Hektar \\
\hline 5 & Lain-lain & 29 Hektar \\
\hline \multirow{2}{*}{} & Jumlah & 350 Hektar \\
\cline { 2 - 3 }
\end{tabular}

Tabel 1. Luas Wilayah Desa Sungai Janiah dan Pemanfaatannya

Kelestarian tembikar tradisional Sungai Janiah sangat dipengaruhi oleh kondisi sosial masyarakatnya, dimana mereka menyadari bahwa sudah merupakan petunjuk panguasa alam memberi peluang kepada ibu-ibu untuk dapat bekerja di rumah sendiri tanpa harus meni-nggalkan tugas lainnya sebagai ibu rumah tangga. Kesadaran yang demikian terbukti dari sikap orang-orang yang memiliki tenaga kuat untuk bertani, mereka tidak ikut campur dalam peke-rjaan membuat tembikar, dan memberi kesem-patan seluas-luasnya kepada ibu-ibu untuk mene-kuni pekerjaan tersebut.

Potensi alam Sungai Janiah yang mendorong berkembangnya kerajinan tembikar adalah tersedianya tanah liat, kaolin, kayu api, jerami, sekam, daun kacang, daun cingkera, batu bulat, batu palinyang, dan sebagainya yang diperlukan pengerajin. Tanah liat sangat banyak persediannya di desa Sungai Janiah (hampir 80\% dari luas wilayahnya). Namun yang paling baik kualitasnya adalah yang terdapat pada lereng bukit, dengan kedalaman $1-2 \mathrm{~m}$, masih bersifat tanah primer (belum mengalamiabrasi air hujan). Oleh sebab itu masyarakat membuat lobanglobang atau galian di lereng bukit, dimana lahan tersebut tidak dimanfaatkan untuk pertanian.

Pengrajin tembikar di Sungai Janiah sangat berkurang jumlahnya (tinggal 5 orang) pada sensus tahun 1999, sedangkan pada masa jayanya sekitar tahun 1950 - 1960-an jumlahnya men-capai lebih dari 300 orang (hampir semua rumah penduduk adalah tempat produksi tembikar). Penyebab berkurangnya jumlah pengerajin adalah berkurangnya permintaan konsumen.

Rumah produksi tembikar adalah rumah tempat tinggal penduduk yang memiliki kolong di bawahnya (rumah gadang). Rumah memang sangat serbaguna dari segi fungsinya seperti tempat tinggal, tempat menyimpan barang-barang, tempat memelihara ternak ayam dan itik, serta tempat produksi tembikar. Masyarakat 245 | Jurnal Budaya Nusantara Vol. 2 No. 1 
membuat sekat-sekat dalam kolong rumah untuk memis-ahkan ruang-ruang untuk memelihara ternak, tempat menyimpan barang-barang, dan tempat produksi tembikar. Kemudian pekarangan rum-ah juga dimanfaatkan untuk berbagai keperluan seperti tempat menjemur padi, tempat jemuran kain, tempat jemuran tembikar, dan tempat pem-bakaran tembikar

Tembikar memang tidak menjanjikan suatu hasil yang besar bagi pengerajin, karena tembikar bukanlah mata pencaharian utama bagi masyarakat. Oleh sebab itu tembikar lebih banyak ditekuni oleh ibu-ibu yang sudah tidak kuat lagi untuk bertani. Sedangkan kaum perempuan yang masih muda, tetap mengandalkan pertanian sebagai lahan pekerjaannya.

Bentuk Tembikar yang dihasilkan pengerajin Sungai Janiah terutama berupa periuk. Periuk ini ada beberapa macam bentuk dan namanya. (lihat Gambar)

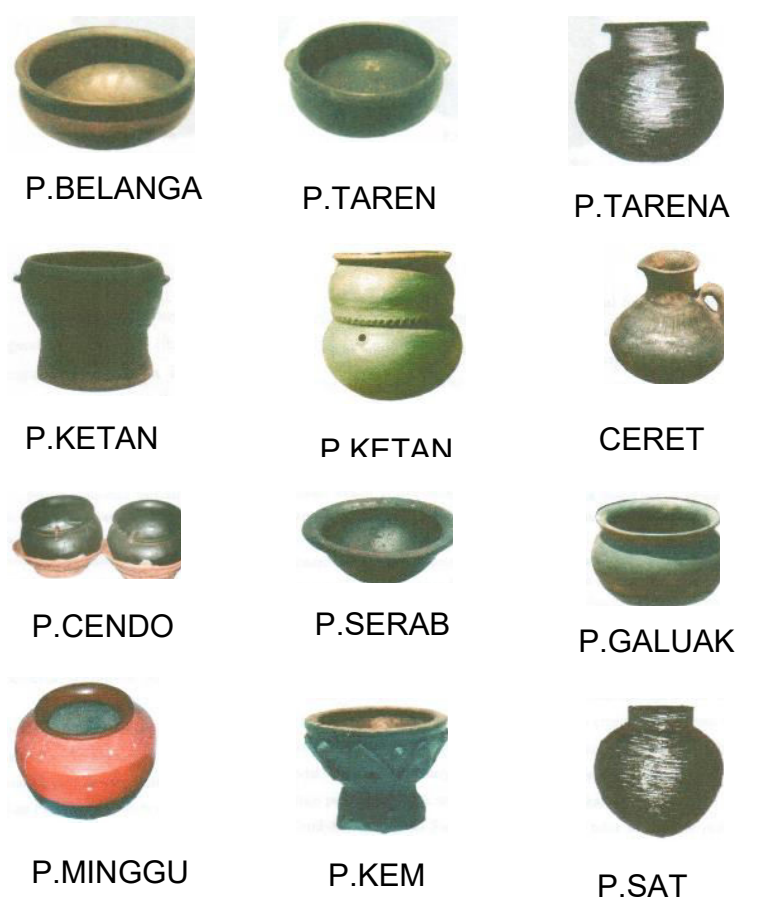

Sumber: data pribadi

246 | Jurnal Budaya Nusantara Vol. 2 No. 1
Pemberian nama ini disesuaikan dengan bentuk dan fungsinya. Nama-nama tersebut antara lain : Pariuak Bala(ngo, pariuak nasi, pariuak katan, pariuak apam, pariuak minggu, pariuak ga-luak, dan pariuak kumayan.Pariuak balango digu-nakan sebagai tempat memasak gulai, pariuak nasi untuk memasak nasi, pariuak katanuntuk mema-sak peganan pulut/ketan, pariuak apam untuk memasak serabi, pariuak minggu sebagai wadah penyimpan beras, pariauak galuak sebagai tempat barang-barang simpanan (yang biasa ditanamkan dalam tanah) dan juga sebagai wadah air untuk berbagai keperluan sehari-hari, dan pariuak kumayan sebagai wadah pembakaran kemenyan.

Bentuk Tembikar Sungai Janiah yang unik dan menjadi ciri khas yang masih diproduksi oleh pengerajin Sungai Janiah adalah sebagai berikut :

Peralatan membuat tembikar antara lain: Pangayuah, Tapo, Bingkai, Tapiak, Batu Bulek, Batu Palinyang, Sabuik Karambia, Daun Taleh, Karuang Mansiang, Sambilu, Pariuak, Bilah Runcing, Galah, Kayu Paapik, Kayu Pangguliak, daun kacang/daun cingkera dan alat-alat bantu

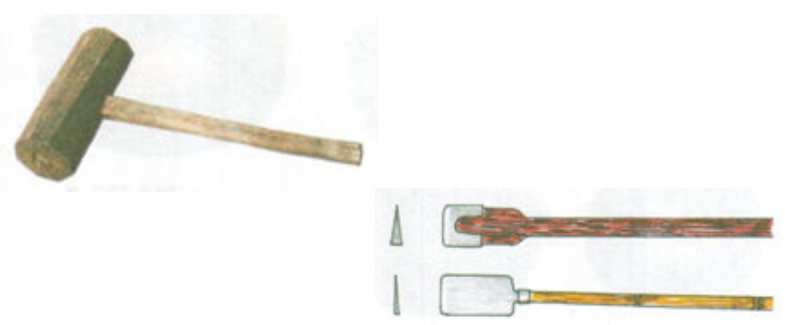

lainnya. Bentuk peralatan pembuatan tembikar Sungai Janiah dapat dilihat pada gambar berikut (sumber: data pribadi) :

tapo pengayuah

batu \& tapiak halus batu \& tapiak kasar laka / bingkai
batu \& tapiak halus

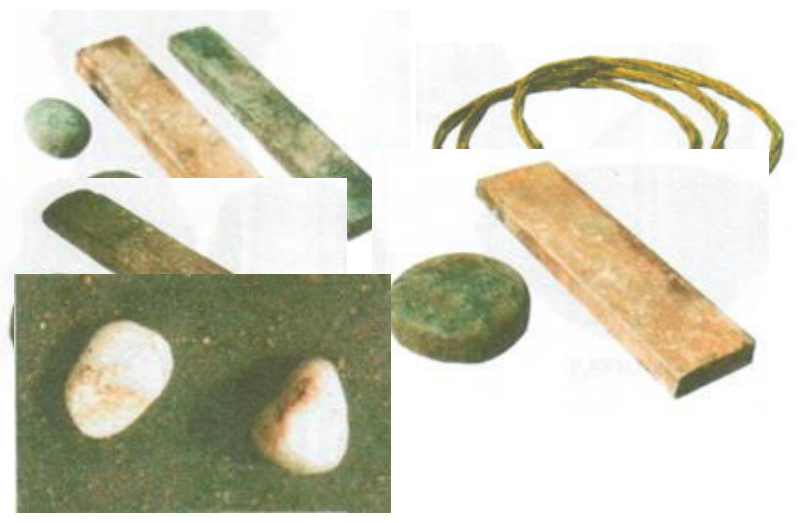


Sumber: data pribadi

\section{HASIL KAJIAN DAN PEMBAHASAN}

Tahap-tahap pembuatan tembikar itu adalah sebagai berikut :

1. Bakanak (beranak/melahirkan) adalah pembentukan awal dengan cara melengketkan tanah liat pada bingkai (lingkaran yang terbuat dari anyaman lidi) membentuk seperti cakram. 2 . Maambuai (membuaikan/mengayun) yaitu dipukul-pukul secara perlahan di atas pelukan (kerena tanah liatnya masih lembut) dengan kayu balok bertekstur dan alas/bandulan dari batu bulat yang bertekstur pula (teknik tatap landas) sehingga cembung ke suatu sisi, 3. Maambuang (diangkat/dilambung-lambungkan) yaitu setelah agak kering pada bagian dasar (yang tadinya dijemur) kembali dipukul-pukul dengan tenik tatap landas, 4. Maurak (membuka) yaitu tem-bikar yang tadinya dijemur, setelah agak kering bingkainya dibuka, dan bagian samping tembikar kembali dipukul-pukul dengan teknik tatap landas untuk mencapai seberapa cembungnya yang di-inginkan sekaligus memadatkan partikel tanah liat serta meratakan ketebalan tembikar dan me-ratakan permukaannya (bibir) dengan pisau, 5. Mambibia (membibir) yaitu membuat bibir tem-bikar dengan tanah liat yang baru (dibentuk bulat panjang seperti pipa berdiameter 1 inci) dile-ngketkan melingkar pada permukaan/mulut tem-bikar. Selanjutnya dibentuk dengan jari supaya bibirnya tipis dan dibantu melicinkannya dengan menjepitkan daun keladi, menggunakan jari sam-bil diputar perlahan-lahan serta ditambahkan sedikit air, 6 . Malinyang (menorehkan) adalah me-mbuat licin pada bagian luar dan dalam tembikar sehingga tampak mengkilat. Alat yang digunakan adalah batu palinyang (terbuat dari batu pualam putih, licin, bulat sebesar telur ayam kampung).

Aktivitas membuat tembikar dapat dilihat pada gambar berikut (sumber: data pribadi):
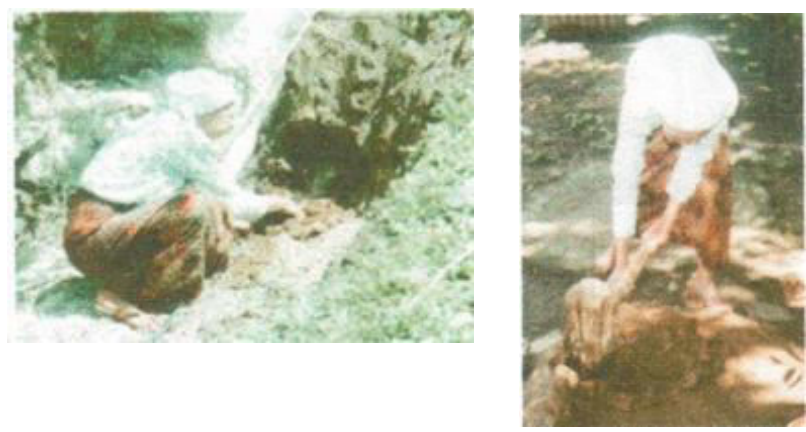

Mengambil

Manap

Maluny

Maluny

Bakan

Maambu

Sumber: data pribadi

Kebanyakan dari tembikar tradisional Su-ngai Janiah tidak memiliki dekorasi atau hiasan. Kondisi yang demikian juga ditentukan

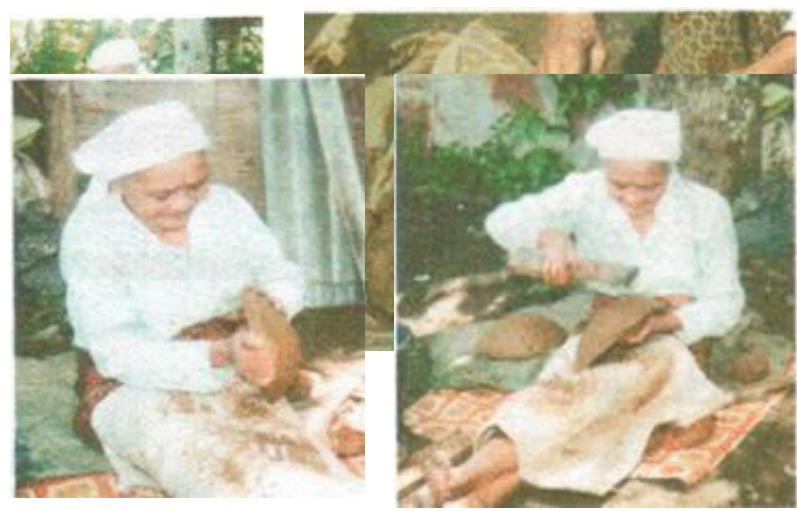

oleh as-pek-aspek desain seperti kemudahan dalam pem-buatan, kemudahan dalam penggunaan dan man-faat benda itu sendiri.

Ukuran periuk ini tidak ada yang standar karena pengerajin tidak menggunakan alat ukur resmi, tetapi hanya memperkirakan diameter bingkai (lingkaran pembentuk awal tembikar) dengan jengkal, lebar jari atau pun hasta. Selain itu mereka juga memperkirakan berapa liter air yang dapat dimuat dalam periuk. Secara umum ukuran itu dapat dikategorikan menjadi kecil, sedang dan besar. Kecil dengan diameter kirakira $30 \mathrm{~cm}$, sedang dengan diameter kira-kira 45 $\mathrm{cm}$, dan besar dengan diameter kira-kira $60 \mathrm{~cm}$. Se-dangkan tinggi periuk diperkirakan setengah

247 | Jurnal Budaya Nusantara Vol. 2 No. 1 
dari diameter masing-masing ukuran di atas. Kete-balan periuk antara $4-7 \mathrm{~mm}$, disesuaikan dengan besar dan kecilnya periuk (semakin kecil semakin tipis).

Bagi masyarakat pedesaan, mereka lebih suka menggunakan wadah ini untuk memasak gulai jika dibandingkan dengan wadah lain seperti aluminium. Hal ini disebabkan karena rasa masa-kannya lebih enak daripada dimasak dengan wa-dah aluminium. Faktor lain pendukung lebih ena-knya masakan itu adalah bahan bakarnya dari kayu api atau arang. Berbeda sekali rasanya de-ngan menggunakan bahan bakar minyak tanah. Masakan tahan lama tidak cepat basi, dan aroma masakan lebih alami (khas) bukan aroma penye-dap rasa.

Potensi Revitalisasi Tembikar Sungai Janiah

Ada beberapa hal sebagai penyebab lestarinya tembikar Sungai Janiah yaitu : a) rendahnya pengetahuan dan keterampilan pengerajin untuk mencipta bentuk-bentuk baru, b) tuntutan ekonomi yang mengharuskan mendapatkan uang dalam waktu singkat, c) sumber daya alam (SDA) lingkungan setempat yang potensial untuk tum-buhnya kerajinan tembikar secara ber-kesinam-bungan, d) sistem sosial masyarakat yang men-dukung terciptanya kondisi yang baik bagi per-kembangan kerajinan tembikar, dan e) masih ada-nya permintaan konsumen walaupun sedikit.

Pembinaan oleh pemerintah guna melakukan perubahan bentuk pada kerajinan tembikar tradisional Sungai Janiah sudah semenjak lama dilakukan (mulai tahun 1975), dimana Dinas Peri-ndustrian Kabupaten Agam Sumatera Barat me-mberikan bimbingan dan pelatihan peng-gunaan alat putar keramik, merancang desain bentuk dan ragam hias yang baru. Namun pelatihan tidak membuahkan hasil seperti yang diharapkan pem-erintah yaitu terjadi perubahan bentuk, fungsi, dan dekorasi, sehingga harga bisa meningkat. Tet-api selesai masa pelatihan pengerajin kembali ke-pada cara lama. Hal ini disebabkan perubahan memerlukan waktu cukup lama dan begitu juga dengan usaha perluasan pasar. Pengerajin tidak betah berlatih 248 | Jurnal Budaya Nusantara Vol. 2 No. 1 dalam waktu lama, dan mereka ingin memperoleh uang dalam waktu singkat. Sedangkan dengan cara lama mereka bisa bekerja cepat dan langsung diserap pasar.

\section{SIMPULAN}

Kelestarian tradisi kerajinan tembikar tradisional di Sungai Janiah masih tetap terjaga sampai sekarang. Hal ini terungkap dari proses produksi yang masih menggunakan cara lama, mulai dari pengolahan bahan, pembentukan, pengeringan, pembakaran dan finishing. Jenis tembikar yang diproduksi oleh pengerajin di Sungai Janiah terbatas pada jenis periuk.

Fungsi dari tembikar Sungai Janiah terutama untuk kebutuhan praktis di rumah tangga seperti wadah memasak, wadah makan-minum, dan wadah penyimpanan makanan. Fungsi lain yaitu sebagai wadah dalam kegiatan religi dan upacara misalnya wadah air suci, wadah kemenyan, wadah penguburan plasenta bayi.

Makna-makna yang terkandung dalam kerajinan tradisional Sungai Janiah, terim-plikasikan dalam bentuk-bentuk prilaku pengrajin yang dapat dijadikan pedoman hidup bagi masyarakat. Makna yang terimplikasi dalam bentuk tembikar tersebut adalah "Kesederhaan", yang mana bentuk tembikar adalah bulat, tidak banyak variasi, dan tidak memiliki ragam hias, sehingga mudah digunakanan atau dibersihkan.

Perubahan desain bentuk, maupun ragam hias hampir tidak dirasakan pada kerajinan tembikar tradisional Sungai Janiah. Transformasi yang terjadi pada berbagai aspek kehidupan ma-syarakat Sungai Janiah, ternyata tidak mem-bawa dampak terhadap tradisi kerajinan tembikar.

\section{DAFTAR PUSTAKA \\ Sebagai Acuan}

Adhyatman, S dan Ridho, Abu.

1984 Tempayan Di Indonesia.Himpunan Keramik Indonesia. Jakarta. 
Bakker, Anton.

1995 Kosmologi dan Ekologi, Filsafat Tentang Kosmos Sebagai Rumah Tangga Man-usia. Penerbit Kanisius. Yogyakarta.

Bastomi, Suwaji.

1988 Apresiasi Kesenian Taradisional. IKIP Semarang Press. Semarang.

Budiwiwaramulja, Dwi.

1998 Gerabah Kasongan, Tinjauan Visual Ten-tang Produk Gerabah Hias Kasongan Sejak Tahun 1960-1997. Tesis. Seni Mur-ni. Program Magister Seni Rupa dan Des-ain. ITB. Bandung.

Esten, Mursal.

1993 Minangkabau, Tradisi dan Perubahannya. Penerbit Angkasa Raya. Padang.

Gustami, SP.

1983 Perkembangan Mutakhir Seni Kriya di Yogyakarta, dalam Berkala No. 3 Januari 1983. Jakarta.

1991 Seni Kriya Indonesia, Dilema Pembinaan dan Pengembangannya. Dalam Seni. Jurnal Pengetahuan dan Penciptaan Seni. No. 1/03 Oktober 1991. BP ISI. Yogy-akarta.

1992 Filosofi Seni Kriya Tradisional Indonesia. Dalam Seni. Jurnal Pengetahuan dan Pen-ciptaan Seni. No. 11/01 Januari 1992. BP ISI. Yogyakarta.

Amiruddin.

2003 Hasil Infestigasi Tentang Tembikar Tradisional Sungai Janiah. Surat Pribadi Kepada Penulis. Bukittinggi.

Hakimi, Idrus $\mathrm{H}$.

1984 Popok-Pokok Pengetahuan Adat Alam Minangkabau. Penerbit CV. Remadja Ka-rya. Bandung. 